\title{
The Argument of Kampung Tangguh Pancasila as a Process of Strengthening Pancasila as Living Values (a respect note to The late Prof. Dr. Hermanu Joebagio, M.Pd.)
}

\author{
Haryani Saptaningtyas ${ }^{1}$, Akhmad Ramdhon², Ardeti Jeni Abdilla ${ }^{3}$ \\ Universitas Sebelas Maret ${ }^{1,2,3}$ \\ h.saptaningtyas@staff.uns.ac.id, wacana3000@gmail.com, jeniabdilla@gmail.com
}

Article History

accepted 10/04/2021

approved 12/04/2021

published 20/04/2021

\begin{abstract}
This paper is a respect note as well as an afterthought on the ideas of The late Prof. Dr. Hermanu Joebagio, M.Pd. about Pancasila as Living Values and how it was conceptualized as the design of the Kampung Tangguh Pancasila program. Kampung Tanggung Pancasila is a work to present the campus as an academic space and a space for community service as well as a bottom-up approach process that explores the values of Pancasila that were practiced by the community..
\end{abstract}

Keywords: Kampung Tangguh Pancasila, Pancasila, living values

\section{Abstrak}

Tulisan ini merupakan sebuah catatan penghormatan sekaligus refleksi terhadap ide dan gagasan almarhum Prof. Dr. Hermanu Joebagio, M.Pd. mengenai Pancasila sebagai Living Values dan bagaimana hal tersebut dikonsepkan sebagai rancangan program Kampung Tangguh Pancasila. Kampung Tanggung Pancasila merupakan upaya menghadirkan Kampus sebagai ruang akademik dan ruang pengabdian kepada masyarakat sekaligus sebagai proses pendekatan bottom up yang menggali kembali nilai-nilai Pancasila yang dipraktekkan oleh masyarakat.

Kata kunci: Kampung Tangguh Pancasila, Pancasila, living values

Social, Humanities, and Education Studies (SHEs): Conference Series https://jurnal.uns.ac.id/shes 


\section{PENDAHULUAN}

Tulisan ini dibuat sebagai penghormatan kepada almarhum Prof Hermanu, untuk mengenang upaya beliau memformulasikan konsep dan ide kegiatan untuk Pusat Studi Pancasila bertema 'Kampung Pancasila; sebagai living values'. Sebagai perintis dan kepala pusat studi Pancasila (2017- Desember 2020), beliau sedang membangun kolaborasi nasional dengan BPIP. Dua bulan sebelum beliau meninggal, kami terlibat dalam diskusi intensif merumuskan kegiatan bersama untuk mengoperasionalkan nilai nilai Pancasila dan mendesign kegiatan aras kampung yang memungkinkan kerjasama masyarakat dan universitas.

Konsep 'Kampung Pancasila sebagai Living Values' ditujukan untuk mendesign kegiatan yang menginventarisir Pancasila sebagai living values karena sudah dipraktekkan sebagai norma harian masyarakat dan sekaligus mengejawantahan nilai tiga pilar perguruan tinggi, utamanya menghubungkan ranah penelitian dan pengabdian masyarakat. Sebuah cita-cita mulia untuk mendekatkan kampus UNS dengan masyarakat dan komunitas kampung disekitarnya dengan meletakkan masyarakat sebagai sumber pengetahuan, yang perlu diakademikkan. Menuliskan kembali hasil-hasil diskusi kami bersama almarhum, adalah cara kami menghidupkan ide ide beliau dan melanjutkan idealisme beliau, sebagai sosok pecinta Pancasila dan pejuang nilai moral.

Sebagai seorang guru besar pada bidang sejarah politik Islam yang juga merintis lahirnya Pusat Studi Pengamalan Pancasila di UNS, sosok beliau cukup penting terlibat dalam upaya peneguhan UNS sebagai kampus banteng Pancasila yang diresmikan secara resmi pada Upacara Peringatan Hari Kesaktian Pancasila, 1 Oktober 2018. Hal tersebut dilakukan sebagai upaya untuk mencegah terulangnya kejadian sejarah yang merongrong ideologi Pancasila pada masa lalu yakni gerakan Partai Komunis Indonesia (PKI), juga untuk mencegah gerakan radikalisme dan anti toleransi, sekaligus mengajak semua civitas akademika UNS untuk mewujudkan nilainilai Pancasila di dalam kehidupan kampus UNS.

Guna mencapai tujuan tersebut, ada dua komitmen yang dilakukan UNS sebagai Kampus Bentang Pancasila yakni, memberlakukan mata kuliah Pancasila bagi mahasiswa dan mendirikan Pusat Studi Pengamalan Pancasila (PSPP). Pada dasarnya, dengan mewujudkan Kampus Benteng Pancasila akan memunculkan pengarusutamaan nilai-nilai Pancasila, wawasan kebangsaan, dan bela negara bagi civitas akademika UNS.

Komitmen ini kembali dikukuhkan dalam pidoto rektor UNS, Prof Dr Jamal Wiwoho, S.H., M.Hum., pada Upacara Hari Kesaktian Pancasila, 1 Oktober 2019, dengan menunjukkan tantangan berbangsa di era perkembangan teknologi dan informasi dan globalisasi yang menyangkut demokrasi, HAM, good governance, radikalisme dan terorisme. Hingga perayaan upacara hari kesaktian Pancasila 1 Oktober 2020, Prof Hermanu tetap menjalankan amanah sebagai sosok representasi kampus UNS sebagai kampus benteng Pancasila. Aktif dalam diskusi diskusi ilmiah sebagai narasumber dan membangun jejaring di luar kampus, termasuk dengan CSO (civil society organization), organisasi mahasiswa, dan pihak pemerintah. Prof Hermanu berkehendak membangun dasar pijakan baru bahwa pusat studi semestinya tidak hanya berbasis kampus, tetapi juga berbasis gerakan masyarakat dan hubungan baik dengan pemerintah. Disinilah ide tentang Kampung Tangguh Pancasila dilahirkan.

Pengetahuan Prof Hermanu tentang sejarah Islam dan sejarah Kota/Keraton Solo, dan kedekatan beliau dengan Bapak Sumartono Hadinoto, Humas Perkumpulan Masyarakat Surakarta (PMS) dan banyak aktifis muda di kota solo, melahirkan Kafe Bhineka di kampus UNS. Sebuah kafe bagi anak muda yang menjadi ruang bertemu, diskusi dan bercanda bagi pemuda lintas agama dan lintas suku di dalam kampus. Disinilah kami, yang secara usia lebih muda, sering kali diajak berdiskusi untuk membangun mimpi bersama. 
Anak muda tak lagi ditempatkan sebagai subjek doktrinal dari nilai-nilai Pancasila, tetapi dihargai sebagai subjek untuk berdialog. Anak muda diberi ruang berekspresi untuk mengkonsep bahwa nilai moral berdasar Pancasila seperti berperilaku toleran dan saling menghargai sejatinya telah tumbuh dalam perilaku harian ini. Disinilah sejatinya konsepsi Pancasila sebagai living values digali dan dilahirkan dalam konsepsi pengabdian kepada masyarakat yang lahir karena kesadaran semakin fragile-nya kebhinekaan dan semakin maraknya intoleransi dan radikalisasi. Dalam tulisan ini, kami akan membangun argumentasi teori terkait living values dari Pancasila melalui konsep Kampung Pancasila, berdasar pemahaman konteks Solo sebagai living lab Pancasila.

\section{Teori}

Kota Surakarta merupakan kota yang mempunyai beragam aspek dinamis, baik dalam konteks lokus budaya Jawa yang tercermin pada praktek keseharian maupun dalam rangkaian catatan yang menunjukkan dinamika kota konflik perkotaan. Bangunan sejarah kota merupakan toponomi ruang yang dibentuk lewat beragam kepentingan untuk mengelola keberadaan beragam etnis dan tata kelola ruangnya dalam konteks dan kepentingan tradisi maupun kolonial. Dinamika yang membentuk mental warga, mulai dari transisi panjang otoritas tradisi Kasunanan dan Mangkunegaran, transisi Kolonialisasi, transisi Kemerdekaan, otoritas Orde LamaOrde Baru hingga fase akhir selama dua dekade Orde Reformasi bersamaan proses demokratisasi-desentralisasi.

Beragam literatur menunjukan fakta bahwa sejak permulaan abad ini setidaknya kota Surakarta telah mengalami krisis sosial di ruang kota dalam beragam bentuk, baik konflik politik, konflik sosial maupun konflik rasial (Kuntowijoyo, 2004). Salah satu yang tidak bisa dilupakan adalah momen transisi akhir Orde Baru (14-15 Mei 1998) yang menyisakan jejak sangat dalam dan perih bagi setiap warga kota karena kerusuhan massa dengan sentimen rasial, dimana kota luluh lantak. Setidaknya tercatat kerugian fisik yang dialami oleh Surakarta, terhitung Rp. $457 \mathrm{M}$, bangunan fisik yang terbakar 159,758 M/persegi, kerusakan bangunan fisik 119,388 M/persegi dan mematikan 214 unit usaha (Mulyadi, dkk, 1999; Purdey, 2006).

Dan sisi lain konflik dengan sentimen isu rasial, Surakarta juga tidak bisa dilepaskan dengan konteks kontestasi kekuatan Kelompok Radikal Keagamaan/KRK yang sangat masif. Kondisi yang tidak bisa dilepaskan dari geo politik transisi panjang otoritas tradisi dalam ranah perubahannya di konteks Orde Baru dan Orde Reformasi. Beragam peristiwa dalam konstelasi global, nasional maupun lokal senantiasa direspon oleh komunitas KRK di Surakarta dengan dominasi pendekatan Wahabisme (DI/AlMukmin/Usrah/JAT) sehingga memicu dan mengaktivasi gerakan yang lebih luas, dengan tetap menempatkan Surakarta sebagai salah satu simpul (Fananie, 2002; Solahudin, 2011; Purwadidada, 2014; Hadiz, 2019). Surakarta hari-hari ini, menjadi panggung sekaligus ruang-ruang untuk mengkonsolidasikan diri, mengembangkan jejaring dan mengembangkan lingkungan bagi penguatan simpul kelompok KRK yang terus berupaya menjangkau lebih banyak anak muda diruang-ruang kota.

Dalam konteks lebih luas, merujuk temuan-temuan paling akhir dari Maarif Institute (2018); LPPM Unusia (2019); maupun Infid (2019) menunjukan bahwa salah satu masalah pokok di Indonesia yang terkait dengan radikalisme adalah indikasi berkembangnya kondisi lingkungan intoleransi dan ekslusivisme, baik di lembaga pendidikan dan lingkungan masyarakat didukung oleh gerakan transnasional dan kelompok radikal. Kondisi tersebut bisa dilihat pada temuan opini terhadap praktek intoleransi dan radikalisme. Guru 50\% beropini intoleran, berakibat pada opini Siswa 46,09\% menjadi radikal maupun rilis terkait kampus terpapar radikalisme, dimana 39\% mahasiswa 7 PTN simpatik pada gagasan radikalisme (Convey, 2018). Sehingga catatan terkait kekerasan dan ketegangan yang berulang seakan-akan menjadi bukti bara sekam yang mengendap dalam alam bawah sadar warga kota, yang pada 
beberapa peristiwa yang menjadi trajektori baru terkait dengan praktek-praktek intoleransi, rasialisme maupun radikalisme.

Gerakan transnasional memiliki sistem yang memungkinkan berkembang reproduksi aktivis dan wacana kekeraasan yang bersumber dari gerakan radikalisme maupun terorisme (Verkuyten, 2018), dimana anak-anak muda menjadi target dari gerakan tersebut. Data CSRC, PPIM, Convey dan UNDP (2018) yang berdasar pada data survey 18 wilayah dengan 451 responden menyebutkankan temuan-temuan bahwa terdapat $5 \%$ pemuda telah menjadi radikal, dan $6 \%$ mengikuti pola pemikiran garis keras. Fenomena tersebut tentu saja mencemaskan karena reproduksi intoleransi memungkinkan penolakan terhadap multikulturalisme, interfaith dan toleransi, pluralisme, dan demokrasi (Delia Deckard \& Jacobson, 2015), bahkan dapat meningkatkan konflik antar etnik dan agama (ISEAS National Project Survey, 2017). Data dan realitas tersebut jelas mencemaskan bersamaan dengan agenda politik elektoral yang reguler, baik Pemilihan Legislatif, Pemilihan Presiden, Pemilihan Gubernur maupun Pemilihan Walikota/Bupati. Untuk itu, menjadi penting bagi stakeholder yang ada untuk merespon kondisi kota dengan latar yang ada.

\section{METODE}

Tulisan ini bersifat refleksi akademik dan aktifitas sosial yang dilakukan oleh tim Pusat Studi Pengamalan Pancasila UNS pada kurun waktu akhir tahun 2017-2020. Sebuah periode awal perintisan untuk membangun konsep dasar pusat studi. Laporan kegiatan pusat studi, dan notulensi rapat atau diskusi tim dijadikan data primer, sementara data sekunder dikumpulkan melalui desk study.

\section{HASIL DAN PEMBAHASAN Kampung Tangguh Pancasila, sebuah proses penggalian nilai Pancasila sebagai Living Values}

Gagasan program Kampung Tangguh Pancasila (KTP) menjadi salah satu program yang diidealkan untuk merespon dan memunculkan anak muda dan warga kampung sebagai aktor yang memproduksi pesan dan rangkaian agenda yang mempromosikan harmoni-keberagaman berbasis komunitas. Melalui rangkaian kegiatan bersama, para pemuda dan warga kampung yang selama ini dianggap sebagai objek atau target yang dididik, justru ditempatkan sebagai subjek yang mempratekkan nilai Pancasila. Dengan cara ini, maka nilai Pancasila akan dilihat tidak bersifat doktrinal bagi kaum muda, tetapi justru berada dalam mekanisme dialog dua arah, yakni menerima Pancasila sebagai nilai dasar, nilai instrumental dan nilai praktis.

Secara umum, Pancasila sebagai idiologi Negara dan falsafah hidup bangsa Indonesia mengandung 3 (tiga) macam nilai yaitu nilai dasar, nilai instrumental dan nilai praktis. Pengertian nilai dasar adalah suatu yang berharga, bermutu, menunjukkan kualitas, dan berguna bagi manusia. Nilai instrumental merupakan nilai yang menjadi pedoman dalam pelaksanaan nilai-nilai dasar. Nilai dasar belum dapat bermakna sepenuhnya apabila nilai dasar tersebut belum memiliki formasi dan parameter yang jelas dan konkret. Nilai instrumental yang berkaitan dengan tingkah laku manusia dalam kehidupan sehari-hari dikenal dengan sebutan norma moral, sedangkan nilai instrumental yang berkaitan dengan suatu organisasi atau Negara, maka nilai-nilai itu diwujudkan dalam arah kebijakan atau strategi yang dirumuskan selalu pada sumber pada nilai dasar.

Dalam tataran konsep, Kampung Tangguh Pancasila memiliki tujuan, 1) mengkreasi ruang-ruang kultural berbasis komunitas; 2) menjadikan kampung sebagai katalisator untuk meneguhkan Pancasila sebagai living values; dan 3) menjadikan kampung sebagai ruang bagi agen perubahan mempromosikan dan membangun lingkungan Kampung Tangguh Pancasila untuk menghadapi tantangan ideologis dan merespon beragam tantangan bangsa ke depan dalam konteks ke Indonesiaan yang 
dinamis. Sebagai sebuah proses aksi-reaksi-refleksi, kegiatan bersama pemuda dan warga, dapat menjadi upaya penguatan nilai dasar Pancasila dalam kehidupan sehari hari pemuda dan warganya, dan sekaligus menjadi upaya refleksi akademik sehingga kampus dan kampung secara bersamaan mendapatkan penguatan. Kampung dan warganya akan bersikap saling meneguhkan bahwa kampungnya adalah kampung yang tangguh berdasar pada Pancasila, sementara Kampus akan semakin kaya akan pengalaman yang melengkapi dan mungkin mengkritik sebuah teori kebenaran.

Melalui gagasan ini, ada upaya mengaktivasi warga kampung kota sebagai aktor kolektif untuk merancang agenda dan memutus rantai panjang potensi konflik berbasis intoleransi, rasialisme maupun radikalisme sekaligus membuka ruang kolaboratif dan bisa berkesinambungan. Menghadirkan kembali Pancasila sebagai nilai-nilai yang mendasari spiritualisme dan living values menjadi opsi sebagai basis agenda komunitas merespon tantangan intoleransi, radikalism maupun terorisme. Agenda untuk mengaktivasi individu, keluarga, tetangga, lingkungan RT/RW, kampung dan Kelurahan sebagai basis membangun harmoni dengan praktek-praktek baik dan konkret Pancasila.

\section{Pancasila sebagai living values: Sebuah refleksi sejarah dari kampung hingga praktek harian}

Keresahan akademisi terkait kondisi kebangsaan muncul sebagai reaksi dari maraknya radikalisasi yang terasa dalam dunia akademik. Menurut Unusia, (2019) dan Wildan, (2013), salah satu masalah pokok di Indonesia ada indikasi semakin menjamurkan "kondisi lingkungan" yang memungkinkan intoleransi and ekslusivisme berkembang, termasuk di dalam dunia pendidikan dan masyarakat. Menghidupkan kembali nilai-nilai Pancasila menjadi penting melihat tantangan global yang ada terkait gerakan transnasional yang mengikis nilai-nilai Pancasila.

Menurut Kaelan (2008: 114) ada tiga asas dari Pancasila sebagai ideologi terbuka, yaitu nilai intrinsik (nilai konstanta atau nilai dasar), nilai instrumental, dan nilai praksis. Nilai intrinsik atau nilai dasar Pancasila bersifat lestari, artinya tidak dapat diubah dan tidak boleh diubah. Nilai dasar Pancasila yang abadi ditemukan dalam empat alinea Pembukaan UUD 1945. Menurutnya, nilai-nilai dasar ini hidup bermasyarakat, berbangsa, dan bernegara. Sementara nilai Pancasila yang bersifat instrumental dan nilai praksis, bersifat terbuka dan dinamis yang tetap harus mengacu kepada nilai dasar. Wujud nilai instrumental adalah dalam bentuk peraturan perundang-undangan yaitu Undang-Undang Dasar, Undang-Undang, Peraturan Pemerintah, Peraturan Presiden, dan Perda. Dengan demikian dalam konteks harian, nilai-nilai yang bersifat praktis ini ada dan telah dilakukan dalam kehidupan masyarakat. Tantangan utamanya justru terkait cara dan metode penggalian kembali nilai praktis untuk menghidupkan Pancasila sebagai living values.

Kampus UNS sebagai benteng Pancasila diharapkan dapat berperan sebagai katalisator untuk meneguhkan living values dari Pancasila, sekaligus menjadi agen perubahan untuk mempengaruhi lingkungan sekitar melalui Kampung Tangguh Pancasila. Dalam posisinya sebagai katalisator ini memiliki arti sebagai berikut.

1. Kampus sebagai lingkungan pendukung gerakan toleransi dan multikulturalisme akan mensosialisasikan gerakan Pancasila sebagai nilai hidup untuk menghadapi deradikalisasi melalui diskusi bersama lintas agama terkait pengalaman kebhinekaan

2. Stakeholders Kampung akan bersama sama mewujudkan Kampung Tangguh Pancasila

Mempromosikan kembali Pancasila lewat Kampung Tangguh Pancasila dengan semangat berbangsa bertujuan untuk merawat kebangsaan serta mempromosikan gerakan perdamaian yang berkelanjutan. Pancasila sebagai living values berpeluang menjadi ruang dialog berbagai macam wacana ideologis untuk memetakan situasi, 
mendefinisikan masalah dan mencari jalan keluar bersama tanpa prejudice dan berbasis kearifan lokal. Maka living values didefinisikan sebagai lived spirituality (Stringer, 2009) dimana fokus agenda untuk melihat rangkaian strategi pola kultural dengan konteks serta lokalitas bisa menjadi bagian dari upaya menghadapi masalah bersama, termasuk intoleransi, radikalisme dan terorisme.

Dalam kegiatan Kampung Tangguh Pancasila, entitas kampung dijadikan sebagai lokus pendekatan artinya kampong diartikan sebagai ruang bersama warga untuk mendefinisikan dan memformulasikan arah masa depan kampung untuk menghadapi berbagai masalah secara bersama. Sejarah komunitas telah mengajarkan kepada warganya melalui tutur pengalaman bagaimana mendefinisikan masalah, memilih prioritas masalah dan melakukan upaya upaya penanggulangannya. Melalui pendekatan Kampung Tangguh Pancasila, pengalaman lokal akan dipakai sebagai upaya menginvestigasi sebuah sistem dimana Pancasila digunakan sebagai sumber living values yang dipraktekkan untuk menyelesaikan masalah bersama yang kompleks termasuk radikalisme dan intoleransi yang berkembang. Agama, sebagai salah satu faktor penting dalam keseluruhan kehidupan manusia Indonesia, akan dilihat sebagai ruang dialog yang berbentuk praktek spiritualitas harian. Dengan mempraktekkan Pancasila sebagai living values akan dilihat sebagai bagian penerapan tasawuf, dimana agama dan radikalisasi, agama dan intoleransi tidak lagi berada dalam dua kubu yang bertentangan.

Anak-anak muda, perempuan, tokoh masyarakat temasuk tokoh agama menjadi subyek utama dalam mengawal Kampung Tangguh Pancasila dengan goal utama adalah meningkatkan kesadaran pentingnya menerapkan nilai-nilai Pancasila dalam kehidupan sehari-hari. Pemberdayaan ekonomi, akan digunakan sebagai test case penerapan nilai-nilai Pancasila yang mengedepankan gotong royong, keadilan sosial dan keberpihakan pada si miskin dan sekaligus exit strategy program untuk menjamin keberlangsungan program. Dalam kaitannya dengan radikalisme dan intoleransi, beberapa asumsi yang berkembang adalah economic disparity (kesenjangan ekonomi) menjadi pemicu (trigger) munculnya kekerasan berbasis agama.

\section{SIMPULAN}

Konsep Kampung Tangguh Pancasila dapat dijadikan sebagai proses pendekatan bottom up yang menggali kembali nilai-nilai Pancasila yang dipraktekkan oleh masyarakat. Melalui pendekatan ini ada upaya untuk menghindari Pancasila yang bersifat doktrinal menjadi sesuai yang sejatinya dekat dengan nilai spiritual masyarakat Indonesia yang religius. Kampus dan Kampung Tangguh Pancasila merupakan wujud Pancasila sebagai living values. Sebuah tindakan konkrit idealisme kampus UNS untuk membangun ruang agama yang berbeda-beda di kampus adalah wujud pelaksanaan pilar Bhinneka Tunggal Ika, bukan hanya bersifat ruang simbolik. Melalui program Kampung Tanggung Pancasila merupakan upaya menghadirkan Kampus sebagai ruang akademik dan ruang pengabdian sebagai prilaku pokok tiga pilar akademik yang semestinya diteruskan. Dengan demikian kegiatan dan gerakan penguatan nilai Pancasila, dapat dipakai sebagai alat kerja perubahan yang lahir dari komitmen bersama untuk menjadikan Universitas Sebelas Maret sebagai `Benteng dan Pelopor Pancasila:. 
DAFTAR PUSTAKA

CONVEY Indonesia. (2018). CONVEY Report (Volume 1) Kaum Muda Muslim Milenial: Hibridasi Kultural, Konservatisme, dan Tantangan Radikalisme. Jakarta: CRCS UIN Syarif Hidayatullah Jakarta

Delia Deckard, N., \& Jacobson, D. (2015). The prosperous hardliner: Affluence, fundamentalism, and radicalization in Western European Muslim communities. Social Compass, 62(3), 412-433.

Fananie, Z., Sabardila, A., \& Purnanto, D. (2002). Radikalisme keagamaan dan perubahan sosial. Muhammadiyah University Press, Universitas Muhammadiyah Surakarta.

Hadiz, V. R. (2019). Populisme Islam di Indonesia dan Timur Tengah. Pustaka LP3ES.

INFID. (2019). Laporan Publik INFID 2019. Jakarta: International NGO Forum on Indonesian Development (INFID)

ISEAS Survey. (2017). The Indonesia National Survey Project: Economy, Society and Politics. Singapore: ISEAS-Yusof Ishak Institute

Kaelan (2008). Pendidikan Pancasila. Yogyakarta: Paradigma

Kuntowijoyo, 2004. Raja Priyayi dan Kawula: Surakarta, 1900-1915. Yogyakarta: Ombak.

MAARIF Institute for Culture and Humanity. (2018). Menjaga Benteng Kebinekaan di Sekolah. Jakarta: Maarif Institute

Mulyadi, M. Hari; Soedarmono (dkk), Runtuhnya Kekuasaan Kraton Alit: Studi Radikalisasi Sosial "Wong Sala" dan Kerusuhan Mei 1998, Surakarta: LPTP, 1999

Purdey, J. (2006). Anti-Chinese Violence in Indonesia, 1996-1999. NUS Press. Purwadidada,

Fajar. 2014. ISIS: Islam Radikal Ancaman Terhadap Indonesia. http://analisahankamnas.blogspot.com/2014/08/Isis-Islamic-state-in-iraq andsyiria.html.

Solahudin. (2011). NII sampai Jl: salafy jihadisme di Indonesia. Komunitas Bambu.

Stringer, E. C. (2009). 'Keeping the faith': how incarcerated African American mothers use religion and spirituality to cope with imprisonment. Journal of African American Studies, 13(3), 325-347.

LPPM Unusia. (2019) Islam Transnasional Merebak Di Kampus-Kampus Negeri: Ringkasan Laporan Penelitian Kualitatif di Delapan PTN Jawa Tengah dan DIY. Jakarta: LPPM Unusia

Verkuyten, M. (2018). Religious fundamentalism and radicalization among Muslim minority youth in Europe. European Psychologist.

Wildan, Muhammad. (2013). The Nature of Radical Islamic Groups in Solo. Jurnal of Indonesian Islam 7(1): 29-70 